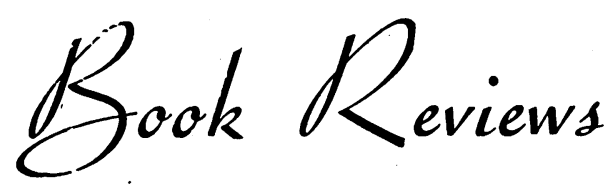

\section{PERIPHERAL NERVE INJURIES}

\section{M.R.C. Special Report, Series No. 282}

Edited by H. J. Seddon. Pp. xvi +45 I, with 276 illustrations. London: H.M.S.O. 1954. £2 155.

All those concerned with the problems of traumatic surgery will welcome the appearance of this book, in which are recorded the results of the work done in the Nerve Injuries Centres of the United Kingdom during the Second World War. The establishment of those centres made possible a most extensive and careful investigation into various aspects of nerve injury, the function of the Nerve Injuries Committee being to guide and co-ordinate the work and to report on the results obtained.

The Committee's Report is evidence of the very high quality of the work done, which undoubtedly has led to a great extension of our knowledge of nerve injuries and of the factors influencing recovery. It covers in great detail the clinical aspects of the subject and analyses the results of nerve suture in a large series of cases. The latter analysis is specially valuable in its bearing on "critical resection lengths' and on 'critical delay periods.' The histopathology of nerve injury is dealt with very fully, and in this connection it is interesting to observe how valuable in a pathological as well as in a clinical sense Seddon's original definition of three grades of nerve injury has proved. In other sections the electrical responses of denervated muscles are considered, and in a very interesting chapter the factors influencing functional recovery are reviewed. Particularly valuable are those sections dealing with Causalgia, with neurovascular lesions and with nerve injuries complicated by fractures, while a new field has been opened up by the work on Nerve Grafting. With regard to the latter, it is interesting to observe the success of the four nerve-pedicle graft operations-this procedure has been of proved value in cases where extensive nerve damage has resulted from a severe vascular lesion or from considerable destruction of soft tissues.

The book is, of course, one for the specialist rather than for the student, though the excellent arrangement and clear presentation of the facts do much to make it easily readable. The lessons of the work done are, however, so valuable, that it is hoped that a shortened version of the report will some time be produced, as an introduction to the study of nerve injuries and as a means of disseminating the knowledge that has been gained.
While all those concerned in the production of this report are to be congratulated on a trul$\vec{D}$ remarkable piece of work, it is right that the work of the editor-in the preparation of the book, ing the work itself and as a member of the Nervo Injuries Committee-should receive special meno tion. The book will be for long the standard work. on the subject, and will form the starting-off poin $\psi^{2}$ for any future research into the problems of nerve injury.

\section{THE BROMPTON HOSPITAL}

\section{The Story of a Great Adventure}

By Maurice Davidson; M.A., D.M., F.R.C.P垔 and F. G. Rouvray, O.B.E. Pp. ix + 152, with $3 \mathrm{I}$ illustrations. London: Lloyd-Lugee Ltd. 1954. 2is.

Until the opening of the Hospital for Consuratp tion and Diseases of the Chest at the Marior Hotex Chelsea, on September 13, 1842, there were n용 facilities in this country for the hospital treatment of pulmonary tuberculosis. Although the Manoo House was a modest beginning, since it held onlo twenty beds, it was soon to be followed by the building of the new hospital in the village of Brompton in Kensington-' a situation remarkable for the salubrity of its air and surrounded entirele. by nurseries and garden grounds.'

The opening of this hospital helped to break the awful taboo which had surrounded pulmonar. tuberculosis, and encouraged the founding of othe similar institutions. The Brompton, howeveri maintained its position unchallenged as Britain's leading chest hospital, and rapidly became world famous. It is easy to understand why this should be so, since from the first the consultant staff included many of the most illustrious figures io. medicine.

This history of the Brompton Hospital has bee ${ }^{P}$ built up from the hospital archives, including the original letters of the founder, Sir Philip Rose, and it is a fascinating story of great enterprise.

Many changes have recently taken place under the new constitution, and the authors are perhaps a little apprehensive for the future. Surely, how ever, so fine a tradition will be maintained, and there is no doubt that it will be strengthened bæ this distinguished book, which is strongly recome mended to all who are interested in the history of chest diseases and the story of a great hospital. 